\title{
LEGAL PROTECTION FOR CHILDREN VICTIMS OF SEXUAL VIOLENCE, IN THE FULFILLMENT OF RESTITUTION RIGHTS
}

Niken Subekti Budi Utami1 ${ }^{1}$ Imam Prabowo ${ }^{2}$

1,2Faculty of Law Universitas Gadjah Mada

Email: niken.subekti@mail.ugm.ac.id; imamprabowo39@gmail.com

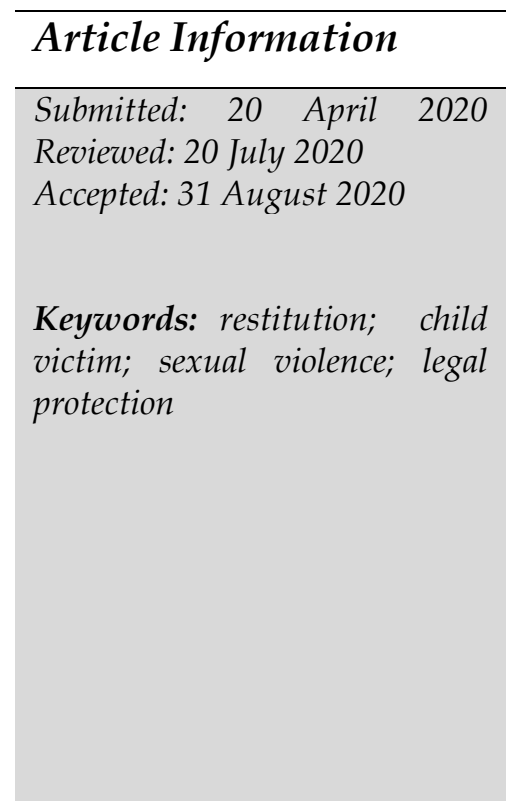

\begin{abstract}
This is an empirical normative study, which aims to determine the legal protection for child victims of sexual violence in the context of law enforcement and the implementation of the right to restitution. In addition, the materials used were primary and secondary data. The legal instrument that implements the rights to restitution for children victims is the arrangement of articles that are unclear and incomplete, resulting in problems. However, bad judges prevent courts from implementing these rights. Unclear and incomplete rules on procedures concerning restitution rights have resulted in an understanding of law enforcement officials, especially in conducting the inter-court application process, and proceedings. Meanwhile, the human resource factors in supporting the fulfillment of restitution are deemed inadequate. The existence of a legal vacuum in the procedures for fulfilling these rights has made the public prosecutor to implement the court resolution and make innovation through consensus decision making.
\end{abstract}

\section{Introduction}

The discussion on the protection of children's rights is gaining special attention from countries around the world. One of which is manifested in the Geneva Declaration on the Rights of the Child in 1924. This declaration demands that children need to be provided with the necessary means for their normal development, either materially and spiritually (Peter Davis, 1974: 61-62). Furthermore, this convention introduced 4 rights, namely the right to life, protection, growth, development, and participation following the declaration (Supeno, 2010: 34).

One aspect of protection that children need is the right to obtain legal protection, since their interaction in community life, which include being perpetrators of criminal acts, witnesses, and victims predisposes them to face the law (Abintoro Prakoso, 2013: 20).

Sexual violence against children often adorns various reports, both through print and electronic media with some of them 
occurring in various forms and modes. Similar to the iceberg phenomenon, it thrives and rife, even when they are not resolved. Based on data from the World Health Organization (WHO) as of September 2016, 12\% of children in the world have experienced sexual violence in the past year. Furthermore, the Indonesian Child Protection Commission (KPAI) recorded that the number of such cases in 2015 - 2017 reached 454.

Based on the data above, child victims of sexual violence need to be given the adequate priority for legal protection, especially those that experience negative impacts in various aspects such as mental health, behavior, physical, economic, and social health, and require long term recovery, with a large amount of money (Ministry of Women's Empowerment and Child Protection, 2017: 20). One of the guarantees of children's legal protection is regulated in Law Number 35 of 2014, concerning Amendments to Law Number 23 of 2002 on Child Protection (Child Protection Law). In the a quo provision, they received special protection as regulated in Article 69A, through social rehabilitation efforts, psychosocial assistance during treatment to recovery, and the provision of protection, as well as assistance at every level of examination. This ranges from the investigation to prosecution, and up to examination at court proceedings. Furthermore, apart from obtaining special rights and protection for child victims, Article 71D paragraph (1) of the Child Protection Law regulates the rights of children victims of violent crimes on the application for restitution from the court. Government Regulation No. 43 of 2017 on the Implementation of Restitution for Child Victims of Crime in article 3, regulates restitution for child victims, in the form of compensation for loss of wealth, for suffering as a result of a criminal act, and/or reimbursement of medical and/or psychological treatment costs.

The legislators believed that in the event of a criminal act against a child, the victim would always bear both the material and immaterial losses. They may include those in the form of shame, loss of self-respect, low self-esteem, or excessive anxiety, which are traumatic in nature. However, these losses need to also be borne by the perpetrator in the form of restitution.

Legal instruments and restitution arrangements instead of providing compensation for the various sufferings experienced by child victims of sexual violence, actually cause various problems. This is because the instruments governing the implementation of the rights to restitution of children victims are unclear and constituted of incomplete articles, resulting in legal loopholes. This Rechtsvacuum causes the judge's verdict or ruling on the right of restitution not to 
be executed. Therefore, the right of the victim is not fulfilled, and the perpetrators are relieved from their obligation. Meanwhile, unclear and incomplete rules of procedure and mechanism for restitution rights ultimately lead to differences in the understanding of law enforcement officials. This is evident in the implementation of the processes involved in submitting and moving proceeding on restitution rights between courts. The human resource factors in supporting the fulfillment of restitution is deemed inadequate, especially in relation to their understanding and calculation of the number of losses suffered by victims.

Problems in the implementation of the right to restitution of children victims of sexual violence cause them to experience double suffering. In addition, Shlomo explained that victims of crime experience deep suffering physically, psychologically, and economically (Simon N. V.J. and Katherine R.R., 2010: 611).

Based on various descriptions of facts and phenomena as described above, it is interesting to study the legal protection of child victims of sexual violence in the context of law enforcement, implementation of the determination, and the right to restitution.

\section{Research Methods}

This study uses an empirical normative legal approach to provide a clear overview of the variables in this legal writing. It was conducted in the Special Region of Yogyakarta and Kulonprogo Regency.

\section{Research Result and Discussion}

As explained above, processes involved in the legal protection for child victims of sexual violence creates problems, especially in the determination and fulfillment of restitution rights. The discussion in this section will be complemented by a case description, followed by a critical analysis of the problems that arise in the case.

\section{A. Restitution Process For Children Victims Of Sexual Violence}

One of the fundamental rights for victims stipulated in the Declaration of Basic Principles of Justice for Victims of Crime and Abuse of Power is to obtain restitution rights. This concept was further accommodated by the state in national legal instruments, through Law no. 31 of 2014 concerning Amendments to Law No. 13 of 2006, on the Protection of Witnesses and Victims, which was thereafter referred to as the Law on Protection of Witnesses and Victims along with Government Regulation No. 7 of 2018 concerning the provision of compensation, restitution, and legal 
assistance to witnesses and victims, and its implementation of regulations, namely the Government Regulation (PP) on Child Restitution. One of the principles used in granting restitution rights is implemented based on the principle of restoration to an original state (restutio in integrum). This principle is based on the effort to return victims of crime to their original condition before the crime occurred even this is not possible (Gumbira, S. W., Handayani, I. G. A. K. R., \& Tedjomurti, K. T., 2019: 199). Furthermore, in this concept, victims and their families need to get fair and appropriate compensation from the guilty person or the third party responsible (Supriyadi Widodo Eddyono, 2016: 16).

According to Muladi, the first thing that needs to be considered in the concept of the implementation of regulations for criminal victims', in regards to their protection is the essence of victims' losses both material and psychological (Muladi, 2002: 16). When the principle of restitution in integrum is viewed from the 'essence of victim loss', it is clear that the legislators have tried to promote the realization of the return of victims to their original state, both from the physical and psychological suffering through the restitution mechanism, namely by filing 'material and immaterial loss' in the submission of the restitution process. This verbis expressly contained in the definition of restitution based on the Child Restitution Government Regulation that restitution is the payment of compensation charged to the perpetrator based on a court decision which has permanent legal force for "material and immaterial loss" suffered by the victim. The word 'immaterial' in legal terminology is defined as 'cannot be proven', therefore, an immaterial loss cannot be proven, recovered, and/or causes temporary loss of the pleasures, fear, pain, and surprise of life. Consequently, it cannot be calculated based on money. This loss is identical to psychological suffering such as shame, loss of virginity, trauma, and fear, which objectively is difficult to prove and calculate. The psychological suffering experienced by a victim is closely related to mental health problems, which requires long term recovery, and a large amount of money (Ministry of PPPA and BPS, 2017: 20)

The mechanism for submitting immaterial losses is further regulated in the Government regulations on Restitution provisions. Article 21 paragraph (3) letter c of the a quo provision states that the request for restitution must be accompanied by evidence of costs that will be or have been incurred during treatment which is legalized by the agency or party conducting the treatment or medication. 
The clause of 'will' in letter $\mathrm{b}$ of the a quo article allows the victims to present their immaterial losses for the psychological suffering they have experienced. Meanwhile, in common terminology, the word 'will' refers to the function of stating something that is going to happen. The psychological impact suffered by the victim in concreto can occur over a long period, therefore, the loss incurred under certain conditions cannot be calculated in 'real' terms. Moreover, the processes involved in the implementation of this loss can create problems because there is no precise calculation standard with which to measure the magnitude of the losses.

Victims of crime that apply for restitution can include suffering components such as shame, trauma, depression as an aspect of the loss to be requested for compensation. Nevertheless, as of now, the extent that components cannot be determined by calculating the benchmarks when converted into currency (interview with Rully Novian, Expert Staff of the Witness and Victim Protection Institute of the Republic of Indonesia (LPSK RI), April 26, 2019). As a solution, LPSK created its mechanism for calculating suffering, which involved quantifying it based on 2 values, namely reasonableness, and appropriateness. This institute tries to ascertain the amount of loss due to suffering, based on rationality, therefore it has the power of proof. For example, when a victim has suffered shame and trauma, the losses incurred need to be paid for based on an assessment of these tragic occurrences with the costs that the victim might incur during the course of repairs. Shame sufferings can be calculated starting from the costs of the counseling needed for recovery, for transportation when going to and returning from the counseling place, and other costs related to the recovery process (interview with Rully Novian, Staff RI LPSK expert, 26 April 2019).

Three factors hinder the implementation of restitution across criminal justice institutions, namely the weak and unclear legislative, the victim's ignorance, and the human resource in law enforcement officers. In practice, the above officers are one of the obstacles preventing the proper and adequate implementation of the submission process and the fulfillment of restitution. In addition, this problem is inseparable from the human resources factor of these officials, especially in the context of their less knowledge and understanding regarding restitution instruments. One example can be seen through the steps of the investigator and public prosecutor in the process and procedures for filing 
restitution. The Government Regulation on Child Restitution regulates the assessment of the amount of restitution as follows:

a. Article 12 paragraph (1) of the a quo provision states that investigators can request an assessment on the amount of request for restitution submitted by the applicant to the LPSK.

b. Article 17 paragraph (1) states that the public prosecutor can request an assessment on the amount of request for restitution submitted by the applicant to the LPSK

When examined carefully, the authority of investigators and public prosecutors to assess the number of requests for restitution in the $a$ quo article has expanded because when compared to the Government Regulation on Restitution, the dominant authority in the restitution stage includes the calculation by LPSK in regards to this topic. The LPSK is placed as the only institution that has various powers, namely accepting requests for restitution submitted by victims, being the only petitioner in court, and even the only institution that calculates and assesses the amount of compensation that is due to victims. Nevertheless, this differs from the Government Regulation on Child Restitution which implicitly gives the main authority to calculate the number of restitution requests to investigators and public prosecutors, and not to the LPSK. When looking at the word elements in Article 12 paragraph (1) and Article 17 paragraph (1) on the a quo provision, the meaning of the word 'can' in a fragment of the sentence "can request an assessment about the amount of the request for restitution submitted by the applicant" and is used to express the discretionary nature of an authority given to a person or institution (Attachment II of Law No. 12 of 2011). Theoretically, the concept of multiple discretionary is expressed by experts such as Alvina Trend Burrows that defined discretion as: "discretion is the ability to choose wisely or to judge for own self" (Alvina Trend Burrows, 1996: 226). Meanwhile, Laica Marzuki defined discretion as the freedom given to administrative bodies or officials in the context of government administration carried out concerning the running, implementation, or administration of government affairs (bestuurzorg) (Alvina Trend Burrows, 1996: 226).

Philipus M Hadjon in Alvina Trend Burrows stated that government discretion must be differentiated into the freedom of wisdom (beleidsvrijheid) and judgment (beordelingsvrijheid). Moreover, freedom of wisdom talks about a situation when statutory regulations give certain powers to government organs, and these organs are free not to use it even though the conditions for their legal use have been met. This provision is commonly 
referred to as authority in a narrow sense. Meanwhile, freedom of judgment is also called the relevant discretionary authority or the law which gives government organs the ability to independently and exclusively assess their power whether the conditions for the implementation of authority have legally been fulfilled or not.

Based on the explanation stated above, it can be understood that "discretionary authority" is freedom of wisdom, when even though the laws and regulations give certain powers to government organs, these organs are free not to use it even though the conditions for their use have been legally fulfilled. Therefore, in this context, it can be understood that an official carries out a discretionary policy on the basis that the authority possessed cannot be used for certain reasons, even though the authority has been given by law. Nonetheless, discretion can be issued when it is still within the authority of the individual.

It has been stated earlier that the word 'can' in the elements of the article indicates the nature of discretionary authority, therefore, the phrase 'can request an assessment of the amount of the restitution request submitted by the applicant to the LPSK' in the provisions Article 12 paragraph (1) and Article 17 paragraph (1) is a discretionary authority owned by the investigator and public prosecutor. The Government Regulation on Child Restitution has explicitly given the authority to calculate the dominant restitution assessment to law enforcement officials, which in this case, are investigators and public prosecutors. Therefore, the author criticizes practices that develop in the scope of law enforcement officers, such as investigators and public prosecutors in conducting the stages of assessing the amount of restitution. This is because irrespective of the fact that investigators and prosecutors that handle child cases have the authority to calculate and assess the amount of restitution submitted by victims, there are still some of these enforcement officials that prefer to calculate the amount of restitution through LPSK.

Based on the results of an interview with Dina Andriani, Head of the PPA Kulonprogo Unit, on May 7, 2019, it was concluded that the practice that has occurred during this time is that immaterial loss has always been submitted by child victims to the LPSK, while the investigator calculates the material losses. For example, peradventure the child victim submits a request for a loss fee of Rp. 50,000,000, but is only able to show a material loss of Rp. 25,000,000, then the calculation of the immaterial loss is Rp. $25,000,000$, and this is what will be submitted to LPSK. In general, 
the process of handling criminal cases against children is to be described as follows:

a. The investigator is obliged to convey information regarding restitution to the victim during the investigation stage, and then, record the evidence in an official report. Furthermore, in a case where the victim does not submit the file, the submission process can be conducted at a later stage, such as through the public prosecutor and the court.

b. The victim submits an application letter addressed to the head of the court because the court decides the case. Moreover, the requirements that need for this process are the child's identity card and proof of loss, which can be in the form of a receipt.

c. The material loss can be assessed by the investigator. However, in regards to the immaterial losses, the assessment process is carried out by the LPSK

Dina Andriani added that the investigator's consideration was to submit the calculation of victims' immaterial losses to the LPSK because there was no proper procedure, either regulated within the internal scope of the police or in the laws and regulations, to calculate the invisible and unproven losses suffered by the victim. Furthermore, the Government Regulation on Child Restitution provides space for investigators to submit an assessment to the LPSK because it is permitted by law. The same applies to the public prosecutor, and in practice, this individual accepts a victim's restitution request under two circumstances (interview with Ujiantari Rahmaniarsi, Public Prosecutor at the Kulonprogo District Attorney, 11 April 2019), including:

1. When investigators do not convey the rights of child victims to apply for restitution, they will not know the procedures and mechanisms for restitution.

2. The process of submitting restitution has been conducted at the investigation stage, but the calculation of immaterial losses by the LPSK has exceeded the time limit, therefore, it has not been completed. Due to the limitation on the period of suspect's detention, investigators continue to delegate cases with the consequence of the complete process of filing for restitution in court to be continued by the public prosecutor

Regarding the first possibility, in a condition when the victim submits compensation which includes psychological damage, the public prosecutor uses the same mechanism, which involves submitting the calculation process to the LPSK. 
This study criticizes the steps taken by investigators and public prosecutors because they seem to ignore the authority given by law to calculate and assess the restitution requests amount submitted by child victims. It is carried out on the pretext that "there is no proper formulation and calculation mechanism". Meanwhile, this fact is detrimental to the victim because the time required for the LPSK to assess the request for restitution is often protracted. Article 12 paragraph (3) of the Government Regulation on Child Restitution states that: "LPSK submits the assessment results about the amount of the request for restitution based on documents submitted by investigators no later than seven days after the application". However, in reality, according to Dina Andriani this period has been fulfilled considering the lack of LPSK resources that are not balanced compared to the number of cases handled. This ultimately impacts the completeness of the case file. To solve this problem, investigators and public prosecutors coordinate with each other regarding the completeness of the restitution files, and in a case where the results of the LPSK assessment have been released, the files will be proposed in the prosecution stage.

The authority transferred to the LPSK to calculate restitution adds to their workload and responsibilities because instead of focusing on child victims of sexual violence, they handle a lot of the process of calculating restitution. Article 11 paragraph 2 of the Law on Protection of Witnesses and Victims stipulates that the LPSK is placed as an institution that has the sole authority in the restitution stages. Meanwhile, by looking at the location of the LPSK, which is only in the capital city of Indonesia, and considering the scope of the union which is very broad, including protecting the rights of victims in 34 provinces throughout the country (interview with Hasto Atmojo Sroyo, Chair of LPSK RI, 26 April 2019), It is feared that the assessment process of the amount of the request for restitution is not being carried out properly and maximally, therefore, the results obtained do not reflect partiality and protection for the victim. It is not impossible that due to the overloaded workload, the calculation process is not carried out carefully, therefore, there is potential for the compensation that needs to have been obtained from the victim through restitution to be lost.

The transfer of the authority to calculate the amount of restitution from investigators to the LPSK did not solve the problem because the LPSK does not have an internal mechanism that regulates the calculation and examination of the losses and 
sufferings that are experienced by victims, especially those that are immaterial (interview with Rully Novian, Expert Staff of LPSK RI, 26 April 2019). Furthermore, the process of submitting restitution rights in court, either in an ongoing criminal proceeding or through post court decisions, in practice creates problems due to the unclear, and incomplete provisions and procedures for filing for restitution in legal instruments. Therefore it confuses, and a lack of implementable "standards". Unfortunately, the complexity that occurs is even more complicated because the Supreme Court (MA) which holds the highest authority in regards to judicial power has not issued an internal regulation in the judiciary (regeling) that specifically regulates the procedural law mechanism for the process of giving restitution. Meanwhile, the existence of this regulation is a mandate of the Government Regulation on Restitution. Article 31 paragraph (4) of the a quo regulation clearly states that further provisions regarding the technical implementation of requests for the examination of restitution are regulated by a Regulation of the Supreme Court called Perma.

The Supreme Court has formed a Working Group Team called Pokja Team, which is tasked with making changes to the Perma governing the mechanism of applying for restitution (interview with Khoeruman Pandu Kesuma, Judge of the Jogja District Court, March 20, 2019). In addition, this team has taken to the District Courts (PN) in regions, including at the Jogja District Courts to ask for input and suggestions regarding the form and mechanism for submitting a good, rigid and implementable restitution compensation. However, since the team has been established before the time of this study, it has not completed its task.

Differences in the understanding of procedural law and the mechanism for submitting restitution occurred between the judges at the Jogja and Wates District Court. Meanwhile, Khoeruman Pandu Kesuma, a judge at the Yogyakarta District Court, understands the process of this submission before the court's decision is legally binding with the case merger mechanism, as regulated in the provisions of Article 98 of the Criminal Code. While the Wates District Court judge understands it as part of a criminal case trial with an ordinary examination procedure based on the Criminal Procedure Code.

When examined further, it can be established that the opinion stating that the process of filing for restitution is based on the process of merging cases is contrary to the provisions in the 
Government Regulation on Restitution and Child Restitution. This is based on some arguments including, first, the process of merging cases with criminal and civil evidence for the compensation examination. Therefore, it is the provisions of the civil procedural law that apply to the examination of compensation claims (Andi Sofyan and Abdul Asis, 2014: 216 218). Article 101 of the Criminal Procedure Code explicitly states that "Civil procedural law provisions apply to claims for compensation as long as this law does not otherwise stipulate". When the concept of civil evidence in a case merger is used as the basis for the procedure for submitting restitution as referred to in the Government Regulation on Restitution, the implementation procedure is uncorrelated and contradicts one another. The proceeding stages in a civil lawsuit at least consist of a debate between the plaintiff and the defendant, before the lawsuit is continued with the defendant's answers, replications, duplicates, civil evidence, conclusions, and the reading of the judge's decision (Andi Sofyan and Abdul Asis, 2014: 216 - 218). Meanwhile, in the provisions of the Government Regulation on Restitution of Child victims of criminal offenses, victims that wish to file for restitution, do not file a lawsuit in court, but submit a request to investigators. This also negates the time limit for filing a lawsuit in the merger of cases in Article 98 paragraph (2) of the Criminal Code, which states that "in the examination of ordinary procedures and short events where the prosecutor as the public prosecutor is present at trial, a compensation claim can only be filed before the public prosecutor files a criminal charge "(M. Yahya Harahap, 2008: 82).

It has been explained above that child victim of sexual violence that wants to file for restitution do not file a lawsuit in court but requests for restitution, which will be included in the criminal prosecution (reskuisitur) and read out at the trial, with the agenda of reading the criminal charges. Furthermore, the restitution provisions in the Government Regulation on Child Restitution do not at all regulate the civil response process in the articles as in the proceeding process in a civil lawsuit.

Secondly, Article 91 paragraph (1) of the Criminal Procedure Code states that "If the injured parties request a merger of their lawsuit case in the criminal case as referred to in Article 98, the district court shall consider its authority to prosecute the lawsuit, the truth of the lawsuit and the penalty for reimbursement of costs that has been issued by the aggrieved party "phrase" .. the district court considers its authority to adjudicate the lawsuit.. " then the 
guidelines used in the examination of damages are civil procedural law based on absolute competence and especially relative competence. The judge has to carefully examine the residence of the defendant, because in line with the relative competence of the civil procedural law, basically it is based on this residence (Andi Sofyan and Abdul Asis, 2014: 216 - 218). This provision is contrary to the relative competence in the criminal procedure law regulated in Articles 84, 85, and 86 of the Criminal Procedure Code. In the provisions of Article 84 paragraph (1) of the Criminal Code, it is stated that "the District Court is authorized to prosecute all cases regarding criminal acts committed within their jurisdiction". Meanwhile, the principle used in the a quo article is based on the place where the crime is committed, which is otherwise known as locus delicti.

The district court has the authority to judge based on the venue of the crime, in other words, the locus delicti determines the relative authority of the district court to prosecute a criminal case (M Yahya Harahap, 1995: 86). This principle is a general rule in determining relative authority, which is first examined to ascertain the authority of the court in examining a case delegated by the public prosecutor.

In a case where the submission for restitution in the trial is interpreted as a merger of cases, the relative authority refers to the provisions for the merger of cases as described above, and when this is carried out, it greatly limits the space for victims of sexual violence to apply for their restitution rights. This is because the victim can only file a compensation claim when the locus delicti is located at the residence of the defendant since when it is located at a different place, the merger claims that restitution cannot be examined or accepted by the district court on the reason that it is "not authorized to examine".

Thirdly, when the application for restitution in the trial is interpreted as a merger of compensation cases, the amount of restitution claims that the victim can ask the defendant or third party is limited to material losses, since immaterial losses cannot be accepted (niet ontvankelijk). This provision is regulated in Article 99 paragraph (1) of the Criminal Procedure Code which states that "... the district court considers its authority to prosecute the lawsuit, the basic truth of the lawsuit, and the penalty for reimbursement of costs incurred by the injured party."

The context of the 'costs incurred' refers to the money spent, which is otherwise called material costs. Based on the provisions of the article above, the judge's decision is limited to granting 
"reimbursements" that has been incurred by the aggrieved party, such as medical and hospitalization costs, transportation costs, and others. In fact, the legal instrument for filing restitution opens up opportunities for child victims of sexual violence to file both material and immaterial losses, as has been explained in the discussion above. The limitation of compensation that can be submitted by victims in a merger case of the Criminal Procedure Code is merely a simplification of the existing conditions and problems. Furthermore, limiting losses in a case merger that only regulates material loss limits the rights of victims of sexual violence to receive compensation for all the suffering that was experienced, both the material and immaterial. Therefore, proof becomes the central point of case examination in court proceedings. This is because through this proof stage, there is a process, method, and act of proving to show whether the defendant is right or wrong in a criminal case, in a court session. (R. Soesilo, 2012: 57).

When it is based on the opinion that the process of submitting restitution is guided by ordinary procedural examinations (Criminal Procedure Code), in this case, the public prosecutor is obliged to prove the events presented by submitting evidence at trial to be judged by the panel of judges for their correctness. Article 137 of the Criminal Procedure Code states that public prosecutors have the authority to prosecute anyone who is accused of committing a criminal act within their jurisdiction by delegating the case to the authorized court. Based on the explanation above, it can be understood that the prosecutions are confirmations of the results of proving the elements process toward the defendant's guilt through evidence in court. In a contario actus, it can be understood that what is contained in the letter of claim must have been proven during the proving process through evidence.

The process of proving the restitution of child victims in court with regular events is the responsibility of the public prosecutor (interview with Ujiantari Rahmaniarsi, Public Prosecutor of Kulonprogo District Attorney, and 11 April 2019). In this case, the request for restitution has not been raised in the indictment, because based on the provisions of the Government Regulation on Restitution and Child Restitution, the request for restitution has only been published in the prosecutor's letter of demand. However, when the victim has submitted a request for restitution at the stage of investigation or prosecution, the public 
prosecutor will then prepare a process of providing evidence in the trial, therefore the agenda of the trial is proving the facts of the incident, and discussion of the victim's restitution begins to emerge.

After the public prosecutor digs up the victim's information, the victim is asked to present documents showing evidence of costs incurred as a result of the crime that occurred. The letter was then shown to the panel of judges.

The process whereby the judge determines the restitution amount for the request is carried out at the judge's deliberation stage, which comes after the head of the trial states that the examination is closed, and the stages of prosecution, defense, and mutual response between the public prosecutor and the accused or legal advisor have been passed (M. Yahya Harahap, 2008: 265). In deliberation, the panel of judges decides whether the request for restitution submitted by the victim is appropriate or not to be granted. The basis for the consideration by the panel of judges' are (interview with Ujiantari Rahmaniarsi, Public Prosecutor at the Kulonprogo District Attorney, 11 April 2019):

a. The assessment results on the amount of restitution given to child victims. In this case, the panel of judges applies the principle of trust to the letters issued by investigators, public prosecutors, or LPSK, therefore there is no need for further examination and proof of this letter in court.

b. The evidence for the victim's statement regarding the restitution request was submitted at trial.

c. Documentary evidence containing costs incurred by the victim of a crime to recover the impact of the loss suffered.

d. The financial capacity of the defendant and/or the defendant's family to pay the restitution requested by the victim.

The consideration point on whether the request for restitution is granted or not is based on the ability of the perpetrator to pay the requested amount because the Government Regulation on Child Restitution does not contain legal remedies that can be implemented should the perpetrator fail to fulfill his obligations. In addition, the panel of judges strives for the defendant to pay the restitution with a humanitarian and psychological approach, touching the human side of the defendant, such as painting a scenario where it is the defendant's family or the defendant that is the victim of a crime.

In a situation when the judges are hesitant in concluding the restitution submitted by the victim after holding deliberations, 
before the trial agenda for verdict reading, they will again confirm the facts of the trial regarding restitution to the child victim and the defendant (interview with Wanda Andriyenni, Judge of the Wates District Court, 12 April 2019 ). After reviewing the statements submitted by the parties, and the judges have confidence in the information presented and it is in line with the decision to be passed, the agenda for the reading of the decision will be continued, and the verdict will be passed. However, if new facts do emerge during the new trial that has the potential to change the consideration and verdict, the trial will be postponed and rescheduled. During that time, the judges again will conduct deliberations and make corrections to the decisions that were to be passed. Judges' decisions in criminal cases containing restitution can be dropped in line with the victim's request. However, the possibility of being dropped below or above the amount of restitution submitted need not be ruled out, due to the independence and freedom of the judge (Wanda Andriyenni, Judge of the Wates District Court, 12 April 2019).

Based on the explanation above, it can be concluded that the application for restitution through the ordinary procedure, on the examination process in criminal cases goes according to, and does not contradict the provisions of the Government Regulation on Restitution or Child Restitution.

The process of proving restitution in a trial, which is first carried out using the proof system and the principle of minimum proof limit is adhered to by the Criminal Procedure Code. This proof system is spelled out in the provisions of Article 183 of the Criminal Procedure Code, which states that "a judge may not impose a crime on a person except with at least two valid pieces of evidence, therefore, he or she is convinced that a criminal act occurred and that the defendant was guilty of committing it". Furthermore, in this article, it is stated that, "proof according to the means and valid evidence" is emphasized more in its formulation. This can be read in the sentence: adequate evidentiary provisions to impose a sentence on a defendant "at least two valid evidence" (Andi Hamzah, 2012: 256 - 257).

The process of proving restitution in a criminal case trial carried out by the public prosecutor as described is in line with the statutory proof system, which is negatively following the Criminal Procedure Code because in this case, this prosecutor in convincing the judge that a criminal act has occurred, and has resulted in harm to the victim of a crime. Therefore, at least 2 (two) pieces of documentary evidence, in the form of receipts for payment/fees 
need to be submitted after being released by the victim to the panel of judges, including the information from the victim's witness, which essentially conveyed the impact of the loss suffered as a result of the criminal act.

Second, proof of restitution in a trial has attempted to meet the minimum limit principle of proof. Article 183 of the Criminal Procedure Code contains the phrase "with at least two valid evidence items", which aims to impose a sentence on a new defendant when this individual's guilt has been proven by at least two valid evidence. In this case, the public prosecutor has tried to prove that the panel of judges may impose restitution on the accused by submitting the minimum limit of evidence according to the law as regulated in Article 184 paragraph (1) of the Criminal Procedure Code.

Third, the application of the regular examination procedure in filing for restitution is more beneficial for child victims of sexual violence because there are no restrictions, especially regarding the number of damages that can be requested, whether material or immaterial. Furthermore, the implementation of restitution applications using the usual audit procedure tends to save more in terms of cost and time, therefore, it is both effective and efficient.

\section{B. The Process Of Meeting Restitution Rights For Children Victims Of Sexual Violence}

From 2018 to 2019, the Wates District Court handled 3 (three) requests for restitution in the then-ongoing criminal justice trial. Moreover, those three cases were criminal acts of sexual intercourse against minors which are regulated in Article 81 paragraph (1) of Law Number 17 of 2016 concerning Stipulation of Government Regulations in Lieu of Law Number 1 of 2016 concerning the Second Amendment to Law Number 23 Years 2002 concerning Child Protection Becomes a Law (interview with Wanda Andriyenni, Judge of the Wates District Court, 12 April 2019). All the defendants were adult perpetrators, including Stef of age 23, that had intercourse with a child victim, and Kelik, 45, that committed the same crime, however, with his stepchild. In the case of Stef's intercourse, the panel of judges sentenced the defendant to pay restitution of IDR 41,280,000 (forty-one million two hundred and eighty thousand) to the victim (Sleman District Court Decision Number 84 / Pid.Sus / 2018 / PN Wat). Meanwhile, in the case of the criminal acts of violence were 4 perpetrators consisting of 2 adults namely And and PJR, and 2 
children namely $\mathrm{Ra}$ and $\mathrm{Aj}$ forced children to have intercourse, The four perpetrators were sentenced to pay restitution of IDR 30,828,000 (three hundred million eight hundred and twenty-eight thousand) jointly, therefore they each paid IDR 7,707,000 (seven million seven hundred and seven thousand). The total value of this restitution was based on the demands of the public prosecutor, which includes a letter of application from LPSK 375 / 1.5.2.HSKR / LPSK / 05/2018 For the third case, involving the defendant Kelik, 45, the trial process was still ongoing at the time this study was conducted, and the public prosecutor was coordinating with the LPSK to include a request for restitution for the criminal charges.

The criminal case of sexual intercourse of a minor against a child of Rs (15) that occurred in the Kulonprogo Regency in 2018 (Decision number 52 / Pid.Sus / 2018 / PNWat) involved four perpetrators, two of which $\mathrm{Ra}$ and $\mathrm{Aj}$ were still under-age. Nonetheless, based on the court ruling, the panel of judges stated that the minors along with the two older perpetrators were legally and convincingly proven to "commit violence by forcing children to have intercourse with them" as stipulated in Article 81 of the Child Protection Law (Decision number 52 / Pid.Sus / 2018 / PNWat). The prosecutor made a series of efforts to get the perpetrator's family to carry out their restitution obligations, but only $\mathrm{Aj}$ and PJR did. Aj was only able to pay an obligation of IDR 5,000,000 (five million) while PJR paid IDR 500,000 (five hundred thousand) of the total restitution that needed to have been received by the victim of IDR 30,828,000 (thirty million eight hundred twenty-eight thousand).

Based on the description of the case, it can be understood that one of the reasons for the obstruction of the fulfillment of restitution to victims is the absence of a legal mechanism that regulates its follow-up enforcement and implementation. This is the opinion of Lorraine Wolhutter, Neil Oley, and David Denham, stating that their effectiveness of compensation is impeded by the inability of many offenders to make compensation payments and the features in enforcing orders (Lorraine Wolhutter, et. Al., 2008: 210). (The effectiveness of restitution payments is hampered by the inability of the perpetrator to make payments as well as difficulties in enforcing the law on victim restitution, therefore, it can be met).

The Government Regulation on Child Restitution and Restitution as a basic instrument of reference for restitution procedures and mechanisms briefly only regulates the period for 
fulfilling the obligation for restitution that is borne by the perpetrator, along with the additional extension time when the amount is not paid within the specified time.

There is a legal vacuum (rechtsvacuum), especially regarding the role of the prosecutor as an executor of the penalty of paying restitution by the perpetrator. Based on Article 1 point 3 of Law Number 13 of 2004 concerning Indonesian Prosecutors, prosecutors are functional officials authorized by law to act as public prosecutors and implementers of Court decisions that have obtained permanent legal force and other powers based on law.

Like two sides of a coin, the prosecutor is in an unfavorable and contradicting condition because on one hand, they should execute criminal decisions that have permanent legal force. This is based on several reasons, First, laws and regulations delegate the "burden" of execution to prosecutors. It is contained in the provisions of Article 30 paragraph (1) letter b 3 of Law Number 13 of 2004 concerning the Indonesian Prosecutor's Office, in the a quo provision expressis verbis, where it is stated that "in the criminal field, the prosecutor has the duty and authority to carry out the decisions of the court that has obtained permanent legal force." Second, the regulation of national criminal procedure law recognizes prosecutors as the only law enforcement tool that executes court criminal decisions (executive ambtenaar). Article 270 of the Criminal Procedure Code states "implementation of court decisions that have obtained permanent legal force conducted by the prosecutor, for which the clerk sent a copy of the letter to him." Therefore, prosecutors are normatively bound to carry out the "dictums" contained in each of the judges' verdicts, including the verdict punishing restitution to perpetrators. However, on the other hand, all actions and efforts of the prosecutor to implement court decisions are limited by the principle of legality. Law enforcement officials cannot act without basis, because the criminal procedural law framework adheres to the nullum iudicium sine lege principle, which is implicitly contained in the provisions of Article 3 which reads "Judiciary is carried out according to the manner regulated in this law." In simpler language, it means that criminal law enforcement is carried out in a manner regulated by statutory regulations.

According to Mark Cunstanzo (2006: 12), the actions of law enforcement officers to implement the provisions of the criminal procedure law needs to be based on the principles of lex scripta and lex stricta. Lex scripta means that the criminal procedural law which regulates the proceedings with all the available powers 
needs to be written, while the lex stricta means that the rules in this law need to be interpreted strictly, thus the provisions in it cannot be interpreted other than what is written. Therefore, in enforcing and realizing legal certainty, the actions of law enforcement officials are only formally limited in regulating them to avoid contradicting actions with the law. This means that law enforcement does not only refer to the provisions of the material criminal law, but also articles on the formal criminal law (Eddy O.S. Hiariej, 2016: 56).

The importance of the legality principle in the administration of criminal procedural law is based on the consideration of preventing the arbitrariness of the authorities, criminal law enforcement officials. Therefore, the actions of these officers are only allowed when the actions have been regulated solely according to the law and the process of making the legislation is carried out in a transparent and accountable manner. Resultantly, the prosecutor, whether in executing court decisions or other actions that limit the basic rights of the defendant, is only justified when the process and procedures have been regulated in writing and are limited in statutory regulations in a formal sense.

In short, the problem of fulfilling restitution occurs because the prosecutor is unable to take any action to carry out a court decision containing the payment of restitution by the perpetrator, even though it is a sole duty and the authority is present. This situation creates a condition of inner conflict for the prosecutor, where there is a psychological and moral obligation to continue to strive for the fulfillment of restitution, especially for child victims of sexual violence that experience multiple impacts and suffering (interview with Ujiantari Rahmaniarsi, Prosecutor General Prosecutor Kulonprogo, 11 April 2019). Therefore, some of them chose a way out, using innovations, such as taking a humanitarian approach to the perpetrator's family to pay the obligation of restitution to the victim, although this method also does not fully guarantee the victim to get the fulfillment of restitution rights.

One of the innovations in the process of obtaining restitution rights was carried out by the public prosecutor at the Kulonprogo District Attorney (interview with Ujiantari Rahmaniarsi, Public Prosecutor at the Kulonprogo District Attorney, 11 April 2019), and the following steps were taken: First, the prosecutor summoned the perpetrator's family to the office. Perpetrators are not summoned because they are serving imprisonment in a correctional facility. Meanwhile, these summon is made before the period of payment of restitution as mandated by law and are 
given the title "summons to implement the judge's decision" using the witness summons format with the omission of the code P-37 from the top right corner. Second, after the family obliged the summons, they were made to carry out the fulfillment of restitution for the child victim. The prosecutor used a humanitarian and religious approach to the perpetrator's family in the hope that they would show empathy and voluntarily carry out their obligations. Third, when the restitution payment is due, the prosecutor reminds the family to immediately carry out the payment.

The process of paying restitution by the perpetrator's family is carried out in the presence of the family of the child victim or the attorney, and the prosecutor and representatives of the LPSK. Furthermore, in this case it was then published in the official report on the handover of the restitution with the title "Handover of Money" which was signed by the parties present.

In practice, some of the perpetrators' families expressed their commitment to pay the entire amount of restitution that had been decided, while others were only able to pay half of it. Nonetheless, there may be families that are unable to make payments at all because their financial condition is poor. In such cases, the prosecutor cannot carry out any legal remedies anymore, and thus only asks such family to make a statement of commitment, by making a stamped statement. The contents of the stamped statement letter are the amount of restitution that needs to be given to the victim by the perpetrator based on the court's ruling, the amount of restitution covered by the perpetrator's family, the reason the family is unable to carry out restitution in full, the period of payment that is covered by the family, and the full name of the family and signature, affixed with a 6000 stamp.

The fulfillment of restitution rights by the perpetrator or the family in practice is based on self-obedience or self-respect. This means that victims can only get their restitution rights when there is good faith by the perpetrator to fulfill their obligations voluntarily. Meanwhile, this can be reflected in the incasu case, where the total amount of restitution that needed to have been received by the victim was IDR 30,828,000 (thirty million eight hundred twenty-eight thousand) but only IDR 5,800,000 (five million eight hundred thousand) collected.

These are various views related to the occurrence of a legal vacuum in the implementation of restitution, one of which is demanding that the state be present to provide compensation to child victims of sexual violence, when the perpetrator is unable to 
pay for the restitution rights which are their responsibility (interview with Ujiantari Rahmaniarsi, Public Prosecutor of the Kulonprogo District Attorney, 11 April 2019). Against this view, this study has several reflections to note. First, the available legal instruments do not accommodate victims of sexual violence crime for compensation. Till presently, the statutory regulation mechanism only allowed victims of serious human rights violations and victims of criminal acts of terrorism to be entitled to receive compensation. Article 2 paragraph (1) of Government Regulation Number 7 of 2018 concerning Compensation, Restitution, and Assistance for Witnesses and Victims states that "victims of gross human rights violations are entitled to compensation." Meanwhile, Article 7 paragraph (1) of Law Number 13 Year 2006 concerning Protection of Witnesses and Victims expands the scope of victims of criminal acts who are entitled to compensation. This article states that "every victim of serious human rights violations and victims of criminal acts of terrorism are also entitled to compensation". When the legislators want to accommodate victims of sexual violence into the category of those that have the right to receive compensation, at least the first step that needs to be taken is to change the substance of the $a$ $q u o$ articles in the legislative process.

Second, when the compensation payment mechanism is borne by state finances, then budget politics in the State Budget needs to be supportive and adequate. At least, the portion for the payment of compensation needs to be increased considering that the potential for payment of compensation to child victims of sexual violence is quite large every year, and covers the thirty-four provinces throughout the country.

Another view is trying to use an alternative to imprisonment as a subsidiary. In regards to this, the punishment is applied mainly as a substitute when within a period determined by law, the perpetrator fails to pay the restitution obligation. This view needs to first be understood in regards to the purpose of punishment in the national criminal law and the objectives of legislators regarding the concept of restitution. Therefore, a conclusion can be drawn whenever there is compatibility between the two.

The purpose of criminalization in national criminal law can be understood as a whole through the philosophical value of punishment based on the prison system in Indonesia. In this case, legislators want the purpose of punishment according to writing to be placed within the framework of relative (prevention) and rehabilitation theory. Although this cannot be completely 
separated from the absolute theory element which requires punishment as suffering. When looking at the purpose of providing restitution based on the will of the legislators, it is more emphasized in the context of alleviating the suffering and upholding justice for the victims of criminal acts. Until presently, victims of criminal acts bear both the material and immaterial losses themselves. Meanwhile, this loss needs to also be borne by the perpetrator in the form of restitution, as a form of compensation for the suffering of the victim (Muladi and Barda Nawawi Arief, 2005: 2). Therefore, the imposition of restitution payments by the perpetrator in a broader perspective is not only intended to provide retaliation because it also serves as part of efforts to recover victims. This is synonymous with restorative justice theory, which seeks to restore the damage and losses incurred due to criminal acts suffered by victims (Mark M. Lanier and Stuart Henry, 2004: 367).

Perpetrators that are unable to pay restitution and therefore, replaced it with imprisonment are not in accordance with the original purpose of the legislators, which seek to recover losses suffered by the victim of the criminal act, both materially and immaterial. Furthermore, the imprisonment period as a subsidiary for paying restitution is too short, and it encouraged perpetrators to deliberately avoid the obligation of paying restitution because their assets are not at stake. The subsidiary only attempts to restore the perpetrators of crime and public order since the recovery of the victim was not touched.

\section{Closing}

\section{A. Conclusion}

Based on the discussion, the following conclusions can be drawn:

a. The process of proposing and determining the rights of restitution for child victims of sexual violence in practice creates problems due to the lack of clarity and incomplete legal instruments regulating restitution rights at this time. These problems have not yet determined the appropriate standard of calculation to measure the number of immaterial losses for child victims. This is due to the differences in the understanding of procedural law and the mechanisms of applying restitution between courts, as well as a lack of knowledge and understanding by law enforcement officials in handling the process of submitting and determining restitution rights.

b. The existence of a legal vacuum in the procedure for fulfilling the rights of restitution for child victims of sexual violence has made 
the public prosecutor as the party executing court decisions to make some innovations through a deliberation process with the families of the perpetrators.

\section{B. Suggestion}

1. The government or related institutions need to immediately formulate regulations to fill in technical rules for the handling and execution of restitution rights to reduce various problems and obstacles experienced in their implementation.

2. Legal experts and legislators need to encourage the realization of legal instruments regarding the criminal justice system that provides protection and sides with child victims of sexual violence.

\section{BIBLIOGRAPHY}

\section{Books:}

Arief, Barda Nawawi, Muladi. (2005). Teori-teori dan Kebijakan Pidana. Bandung: Alumni

Burrows, Alvina Trend. (1966). The Basic Dictionary of American English. New York: Rinchart and Winston Inc.

Constanzo, Mark. (2006). Aplikasi Psikologi dalam Sistem Hukum. Yogyakarta: Pustaka Pelajar

Davis, Peter. (1994). Hak Asasi Manusia (Sebuah Bunga Rampai). Jakarta: Obor Indonesia.

Eddyono, Supriyadi Widodo. (2016). Masukan Terhadap Perubahan UU Nomor 13 Tahun 2006 tentang Perlindungan Saksi dan Korban. Jakarta: Koalisi Perlindungan Saksi dan Korban.

Hamzah, Andi. (2012). Hukum Acara Pidana Indonesia. Jakarta: Sinar Grafika.

Harahap, M Yahya. (1995). Ruang Lingkup Permaslaahan Eksekusi Bidang Perdata . Jakarta: Gramedia.

(2008). Pembahasan Permasalahan dan Penerapan KUHAP, Pemeriksaan Sidang Pengadilan, Banding, Kasasi, dan Peninjauan Kembali. Jakarta: Sinar Grafika. 
Hiariej, Eddy O.S. (2016). Prinsip-Prinsip Hukum Pidana Edisi Revisi. Yogyakarta: Cahaya Atma Pustaka.

Ministry of Women's Empowerment and Child Protection and Central Bureau of Statistics, 2017, Thematic Gender Statistics: Ending Violence Against Women and Children in Indonesia, Ministry of Women's Empowerment and Child Protection, Jakarta.

Muladi. (2002). Hak Asasi Manusia, Politik dan Sistem Peradilan Pidana. Jakarta: Koalisi Perlindungan Saksi dan Korban.

Prakoso, Abintoro. (2013). Pembaruan Sistem Peradilan Anak. Laksbang Grafika

R. Soesilo. (2012). Hukum Acara Pidana Prosedur Penyelesaian Perkara Pidana Menurat KUHAP Bagi Penegak Hukum. Bogor: Politea.

Simon N. VJ, Katherine, RR. (2010). 'The Psychological Impact of Victimization: Mental Health Outcomes and Psychological, Legal, and Restorative Interventions' in Shlomo Giora Shoham, Paul Knepper, Martin Kett, International Handbook of Victimology, CRC Press, Broken Sound Parkway NW

Sofyan, Andi and Abdul Asis. (2014). Hukum Acara Pidana Suatu Pengantar. Jakarta: Prenadamedia.

Supeno. (2010). Kriminalisasi Anak: Tawaran Gagasan Radikal Peradilan Anak Tanpa Pemidanaan. Jakarta: Gramedia Pustaka Utama.

Wahid Abdul, Muhammad Irfan. (2001). Perlindungan Terhadap Korban Kekerasan Seksual Advokasi atas Hak Asasi Perempuan.

\section{Journals:}

Bandung: Refika Aditama.

Gumbira, S. W., Handayani, I. G. A. K. R., \& Tedjomurti, K. T. (2019). The Urgency of Presidential Policy to Revitalize and Maintain the Existence of Cooperatives Based on Pancasila. Sriwijaya Law Review, 3(2), 199-224.

\section{Legal Documents:}

Law Number 31 of 2014 on Amendment of Law Number 13 of 2006 on the Witness and Victim Protection (State Gazette of The Republic of Indonesia Number 293 of 2014) 
Law Number 35 of 2014 on amendment of Law Number 23 of 2002 on the Child Protection. (State Gazette of The Republic of Indonesia Number 297 of 2014)

Government Regulation Number 7 of 2018 on the Providing Compensation, Restitution and Assistance to Witnesses and Victims (State Gazette of the Republic of Indonesia Number 24 of 2018).

Government Regulation Number 43 of 2017 on the Implementation of Restitution for Children Who Are Victims of Criminal Acts. (State Gazette of The Republic of Indonesia Number 219 of 2017)

Sleman District Court Decision Number 52/Pid.Sus/2018/Pn Wat

Sleman District Court Decision Number 84/Pid.Sus/2018/PN Wat

\section{Websites:}

Setyawan, Davit, 2017, Tahun 2017 KPAI Temukan 117 Kasus Kekerasan Seksual Terhadap Anak, media release 10 July 2017 , viewed 11 July 2019 <http://www.kpai.go.id/berita/tahun-2017-kpai-temukan116-kasus-kekerasan-seksual-terhadap-anak> 